\title{
GRAZING MANAGEMENT AND FACIAL ECZEMA
}

\author{
J. A. Lancashire and R. G. KeOGH \\ Scientific Officers, Grasslands Division, D.S.I.R., \\ Palmerston North
}

IN THE late summer and early autumn, farmers in many parts of the North Island and the most northern areas of the South Island are on their guard against facial eczema. This disease, which occurs in both sheep and cattle, is virtually confined to New Zealand, although isolated outbreaks have been reported in Australia. It was first recorded in New Zealand in 1897 (Gilruth, 1897) and since then there have been several widespread and severe outbreaks e.g., in 1908, 1910, 1935. 1938, 1955 and 1956. It has been known for many years that the irritation of exposed lightly pigmented skin surfaces - the typical clinical svmptoms of the disease $\rightarrow$ is the result of liver damage. The search for this liver-damaging factor (Johns and Filmer, 1960) ; the discovery of the fungus Pithomyces chartarum as the primary cause of facial eczema (Thornton and Percival, 1959) ; and the isolation from it of the toxin Spnridesmin (Synge and White, 1959) is well documented.

Pithom yces chartarum is a spore-forming saprophytic fungus which develops mainly in the summer and autumn when earth temperatures at $4 \mathrm{in}$. are $65^{\circ} \mathrm{F}$ or higher. In the field, rain is necessary both for the infection of dead plant material by fungal spores and also for the rapid sporulation of the fungus (Brook, 1963). These results explain the occurrence of severe outbreaks of facial eczema in vears when a hot dry summer, which causes widespread death of pasture plants, is followed by a warm wet autumn. Spore counts are generally used to assess the development of Pithomyces chartarum in the field (Brook, 1963), and Sinclair (1961) showed a close correlation between spore counts and the severity of liver damage in grazing lambs.

Several well-established methods are available for the prevention of facial eczema. These include grazing on brassica crops or pure white clover swards (Filmer, 1960), or stocking at $200^{-}$to- 400 sheep-l -acre and-feeding--on-hap ( McMeekan, 1956). In some areas these methods are not popular because they do not suit current sheep husbandry practices (Johns and Filmer, 1960). In particular, it is unrealistic to expect farmers to grow a summer crop every year as a precaution against relatively infrequent outbreaks 
of the disease. Also, the facial eczema season frequently coincides with tupping and it is impossible to flush ewes on hay during a shutting-up period. Further, there is a danger of salrnonellosis outbreaks under conditions of reduced nutrition and very high stocking rates (Nottingham and Urselmann, 1961) with the result that in some areas facial eczema may be the lesser of two evils. Ideally a control system is required in which the grazing animal utilizes ample "safe" feed from existing pastures at a reasonable stocking rate. Studies of the ecology of Pitkomyces chartarum (Brook, 1963) and of the dispersal of fungal spores (Smith et al., 1962) have shown that this might be achieved through grazing management. Recently more detailed information on this aspect has been obtained at Grasslands Division, Palmerston N orth.

Botanical Changes and Dead Matter Accumulation in Ryegrass/White Clover Pastures in the Summer and Early Autumn

As Pitkomyces chartarum grows only on dead plant material, information was required on the nature and causes of dead matter accumulation in ryegrass/white clover pastures during the summer and early autumn. Therefore, pastures of Ruanui ryegrass/white clover, Manawa ryegrass/white clover and Äriki ryegrass/white clover were sown in March, 1962, on a freedraining Manawatu fine sandy loam. Following emergence, the pastures were grazed periodically with sheep to establish a wellbalanced grass/ clover sward. There were four replications and the paddock size was one-tenth of an acre. During the measurement period, grazings were carried out on January 12 and February 2. All pastures were moderately grazed to 2 to 3 in., except for a lax grazing to 4 to 5 in. of the Manawa pasture on January 12 to maintain the grass component. After grazings in mid-November and on February 2, all pastures were topped to $3 \mathrm{in}$. with a sickle bar mower. The data presented in Table 1 were obtained from four 1 sq. $\mathrm{ft}$ quadrats/paddock aut to ground level with surgical scissors.

There was generally more live and less dead ryegrass in the Ariki pastures than in the Ruanui pastures. The results confirmed reports (Sears, 1961) that Ariki ryegrass outyields Ruanui during the summer. If, as Corkill (1963) suggested, Ariki tends to replace Ruanui in farm pastures, there may be a lessening of the facial eczema problem because of a reduction in the quantity of substrate available for Pitkomyces chartarum. 
Grazing Management \& Factal Eczema

TABLE 1: MEAN YIELDS OF LIVE AND DEAD HERBAGE COMPONENTS IN THREE GRAZED RYEGRASS/WHITE CLOVER PASTURES AT FOUR SAMPLING DATES

(lb D.M./acre to ground level)

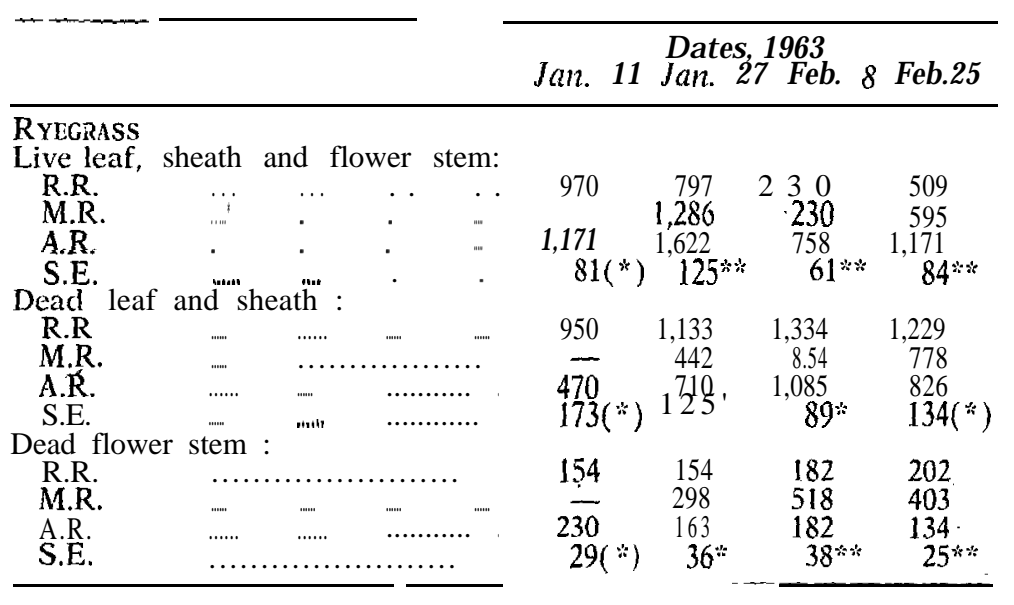

CLOVER

Live leaf, flower stem, petiolc and stolon :

\begin{tabular}{|c|c|c|c|c|c|c|c|c|}
\hline R.R. & - 'm- & ..... & & $\cdots$ & 845 & 461 & 432 & 422 \\
\hline M.R. & ..'” & ....... & & . & - & & 374 & 662 \\
\hline $\begin{array}{l}\text { A.R. } \\
\text { S.E. }\end{array}$ & ."n' & ..."' & ...' & ..... & 662 & $1,0,56 \quad 505$ & 144 & 250 \\
\hline $\begin{array}{l}\text { S.E. } \\
\text { ead leaf ar ar }\end{array}$ & innet & ....... & & & & $115^{*}$ & $47^{* * k}$ & $89^{*}$ \\
\hline R.R. & . & He: & 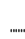 & ...... & 29 & 67 & 38 & 29 \\
\hline M.R. & ....." & .......... & .... & ...." & - & 96 & 58 & 29 \\
\hline A.R. & ....... & ....... & ...' & ... & 29 & 38 & 38 & 10 \\
\hline S.E. & $\ldots . .$. & $\ldots . . .$. & ..'- & .... & 19 & 58 & 27 & 12 \\
\hline R.R. & stem & 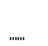 & - & .."' & nil & 58 & 10 & 19 \\
\hline M.R. & m & $\ldots$ & 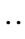 &.. & - & 29 & 29 & nil \\
\hline A. $R$ & 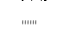 & 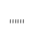 & . & ... & nil & 87 & 10 & 10 \\
\hline S.E. & &.. & ...." & ....." & & $13(*)$ & 8 & \\
\hline
\end{tabular}

R.R. Ruanui ryegrass/white clover pasture

M.R. Manawa ryegrass/white clover pasture

A.R. Ariki ryegrass/white clover pasture

$(*) p<0.1 \quad * P<0.05 \quad * 0<0.01$

After the grazing on January 12, two grazing cages were placed in each replicate to represent a spelled-area.-The herbage yields obtained from one 1 sq. ft quadrat/cage cut to ground level are shown in Table 2 .

By March 11 there was more dead ryerrass leaf and sheath in the Ariki pastures than in the other swards. It appeared that the vigorous growth of the Ariki ryegrass 
TABLE 2: MEAN YIELDS OF LIVE AND DEAD HERBAGE COMPONENTS IN THREE SPELLED RYEGRASS/WHITE CLOVER PASTURES AT THREE SAMPLING DATES

(lb D.M./acre to ground level)

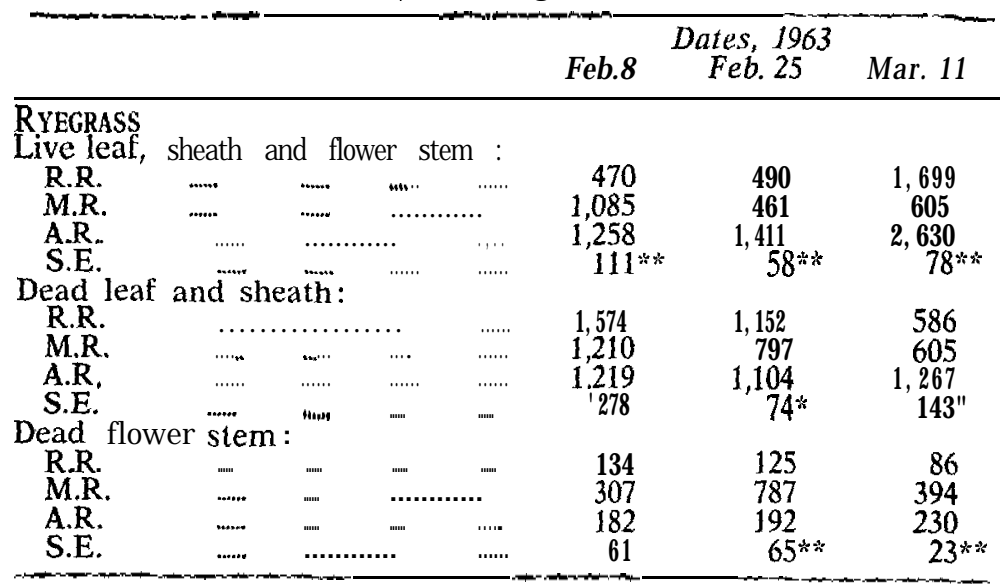

CLOVER

Live leaf, flower stem, petiole and stolon :

\begin{tabular}{|c|c|c|c|c|c|c|c|}
\hline $\begin{array}{l}\text { R.R. } \\
\text { M.R. } \\
\text { A.R. } \\
\text { S.E. }\end{array}$ & 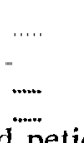 & .". & $\begin{array}{l}7 . . . " \\
. . . . \\
. . .\end{array}$ & .... & $\begin{array}{c}365 \\
1,018 \\
326 \\
115 * *\end{array}$ & $\begin{array}{r}451 \\
1,363 \\
355 \\
154 "\end{array}$ & $\begin{array}{c}605 \\
1,910 \\
384 \\
192 " ' \text { " }\end{array}$ \\
\hline $\begin{array}{l}\text { R.R. } \\
\text { M.R. } \\
\text { A.R. } \\
\text { S.E. }\end{array}$ & $\ldots$ & $\cdots$ & 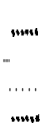 & $\ldots$ & $\begin{array}{l}67 \\
173 \\
86 \\
30(*)\end{array}$ & $\begin{array}{l}29 \\
77 \\
77 \\
25\end{array}$ & $\begin{array}{l}48 \\
250 \\
115 \\
36 \text { ** }\end{array}$ \\
\hline $\begin{array}{l}\text { R.R. } \\
\text { M.R } \\
\text { A.R. } \\
\text { S.E. }\end{array}$ & ; & 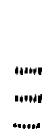 & $\ldots$ & 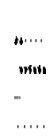 & $\begin{array}{c}58 \\
240 \\
67 \\
44^{* *}\end{array}$ & $\begin{array}{c}48 \\
144 \\
77 \\
70\end{array}$ & $\begin{array}{l}29 \\
58 \\
48 \\
29\end{array}$ \\
\hline
\end{tabular}

(*) $P<0.1 \quad * P<0.05 \quad * * P<0.01$

probably caused intense shading in the base of the sward with a resultant increase in leaf death. Clearly the advantage shown by Ariki over Ruanui in Table 1 may be nullified by different management systems.

In all grazed and spelled pastures, ryegrass leaf and sheath was the major component of the dead material with smaller amounts of dead ryegrass flower stem and dead clover. However, pasture topping probably reduced the ryegrass flower stem component, because it appears from the condition of untopped farm pastures during the sum- 
mer that flower stem may form a substantial proportion of the dead material. The greater quantity of dead flower stem in the Manawa pastures was probably the result of the later (Barclay, 1963) and more prolific flowering (Brougham, 1961) of this species.

Spore counts of Pitkomyces ckartarum showed 5 to 10 times as many spores/ gram dry weight on dead ryegrass leaf and sheath than on dead ryegrass flower stem (Lancashire and Keogh, unpublished). Brook (1963) found that dead Manawa ryegrass leaves were more rapidly utilized by the fungus than dead prairie grass flower stems. It is suggested that pastures where the dead material is predominantly leaf will be more conducive to the rapid development of the fungus than pastures where flower stem comprises a high proportion of the dead material. However, the freeflowering ryegrass varieties like Manawa and Paroa are more likely to die out during the summer than the perennial varieties which have a lower ratio of flowering to nonflowering tillers (Soper, 1958). In particular, Brougham (1960) showed that frequent hard grazings ( 3 to 1 in.) of Manawa ryegrass/ white clover pastures during the summer caused widespread death of ryegrass plants. However, it does not necessarily follow that there will be more dead material in a hard grazed pasture than in a laxly grazed or spelled pasture. This is illustrated by the results in Table 3 which were obtained from two small areas (onetwenty-fifth of an acre) of a M anawa ryegrass/white clover pasture during the summer of 1964 . The pastures were rotationally grazed (5 to 2 in.) until early January when one was spelled and the other hard grazed once to 1 in. on

TABLE 3: MEAN YIELDS OF LIVE AND DEAD HERBAGE COMPONENTS IN SPELLED AND HARD GRAZED MANAWA DATES

(lb D.M./acre to ground level)

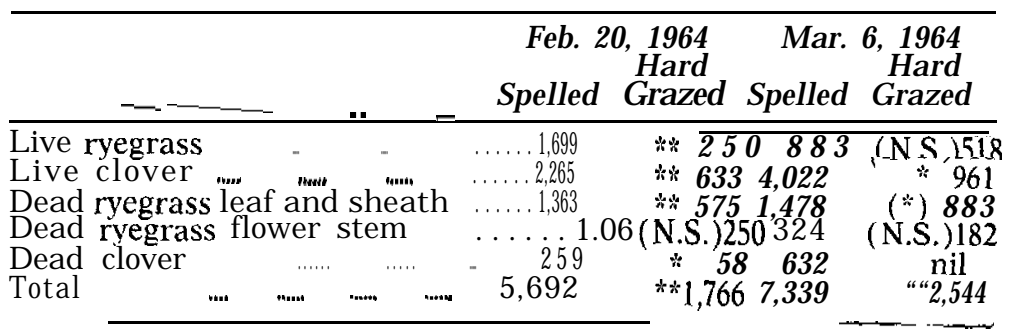
(*) $P<0.1$
* $P<0.05$
* $p<0.01$ 
February 2. Herbage samples were obtained from four $10 \mathrm{ft} \times 3$ in. strips/ paddock cut to ground level with a modified sheep shearing handpiece.

The smaller quantity of dead material in the hard-grazed pasture was mainly the result of the large reduction in total herbage. Brook and Mutch (1964) showed poorer development of Pitkornyces chartarum and less facial eczema on Ruanui ryegrass/ white clover pastures hard grazed by 10 sheep/ acre than on similar pastures stocked at 5 to 6 sheep/acre. This result was attributed to the smaller quantity of dead material in the hard-grazed pasture. However, some disease still occurred and animal thrift was considerably reduced by the lack of feed. This method of control possesses little advantage over the shutting-up procedure mentioned earlier.

A nother aspect of the results is the very small yield of dead clover in all the grazed pastures (Tables 1 and 3). Substantial amounts occurred only in long spelled cloverdominant pastures (Tables 2 and 3). This was probably the result of intense shading caused by the development of a dense canopy of clover leaves (Brougham, 1958). Only one case of high spore numbers of Pitkomyces chartarum in a pure white clover sward has been reported. It was suggested that the development of the fungus was encouraged by a large accumulation of dead clover following a severe infection of Sclerotinia trifoliorum (Sinclair, unpublished). However, Smith (1964) suggested that high spore loads may occur on short white clover if substantial quantities of dead weed grasses are present. The accumulation of dead material may also be reduced by rapid decomposition of dead clover leaves (Brougham, 1958). It appears that very little dead clover occurs in pure clover or mixed swards provided disease and intense shading are avoided. This is probably one reason why pure white clover swards are relatively "safe" during outbreaks of facial eczema.

Frequent hard grazings (3 to 1 in.) (Brougham, 1960) or long spellings (Tables 2 and 3 ) of Manawa ryegrass/ white clover pastures in the M anawatu during the summer generally produce a strongly clover dominant ( 70 to $80 \%$ ) sward by the early autumn. In the drier Poverty Bay-East Coast area, spelling of similar pastures before the onset of dry conditions, usually in early December, gives virtually pure clover swards by late summer (Sinclair and Simpson, 1954). In general, the proportion of white clover in ryegrass/white clover pastures during the summer is related to the persistency of the ryegrass variety. Soper (1958) suggested that 
an important factor in ryergass persistency is the successful establishment, after flowering, of well-rooted vegetative tillers before the onset of dry conditions. Varieties with a short, early flowering period like Ruanui and Ariki (Barclay, 1963) suit this requirement rather better than Manawa which has a prolonged and later flowering period (Brougham, 1961).

It is suggested that the development of clover-dominant Manawa ryegrass/ white clover pastures during the summer should produce a relatively "safe" pasture by the time facial eczema is prevalent.

The Intake of Herbage and Spores of Pithomyces chartarum by the G razing Sheep

As Pithomyces chartarum is a saprophytic fungus, the origin of fungal spores is the dead plant material which is generally found in the lower levels of a pasture. However, spores may be dispersed on to green leaves by animal movement, rain, wind currents, or through continuous water films (Smith and Crawley, 1964). As the relative number of spores on green leaves is generally lower in tall pasture than in short pasture (Brook, 1963 ; Smith et al., 1962), and more cases of facial eczema occurred on short pasture than on long pasture (Smith et al., 1963), it appeared that it might be possible to reduce spore intake by grazing management.

The use of oesophageal fistulated sheep (Torell; 1954) made possible the direct measurement of herbage and spore intake by the grazing animal. A uniform group of five six-tooth Romney wethers and one six-tooth Romney ewe with oesophageal fistulas were used in the experiment. They were grazed on three occasions on a small paddock (one-twenty-fifth of an acre) 'of a two-year-old Ruanui ryegrass/ white clover pasture which had been rotationally (4 to 1 in.) grazed since establishment. The grazings were carried out at different heights to simulate the progressive grazing-down-of-a-tallLpasture.J?-ior to the experiment the sheep were grazed on ryegrass/white clover pastures, and during the four days of the trial remained on the experimental paddock. These precautions were taken because Arnold et al. (1964) showed that unreliable results were obtained from oesophageal fistulated sheep if they were unaccustomed to grazing a particular pasture type. Prior to each grazing the herbage yields' above and below 1 in. were 
obtained from six 1 sq. ft quadrats. Spore numbers/ gram dry weight were obtained by a wash and haemocytometer count method (Lancashire and Keogh, unpublished) from three samples of approximately $10 \mathrm{~g}$ of herbage cut above and below 1 in., and from three $1 \mathrm{~g}$ samples of each of the herbage components. During each grazing, which lasted 1 to 2 hours, 3 to 5 herbage collections were made from each animal and a $5 \mathrm{~g}$ sub-sample removed for herbage dissection and spore counts.

Table 4 shows the herbage yields obtained on the three days of the experiment.

TABI.E 4: MEAN YIELDS OF HERBAGE COMPONENTS AT TWO LEVELS IN A RUANUI RYEGRASS/NHITE CLOVER PASTURE GRAZED AT THREE HEIGHTS

(Ib D.M./acre)

\begin{tabular}{|c|c|c|c|c|c|c|}
\hline & \multicolumn{4}{|c|}{ Date, 1964} \\
\hline & & & Apr. 4 & Apr. 6 & \multicolumn{2}{|c|}{ Apr. 7} \\
\hline \multicolumn{7}{|l|}{ ABOVE ONE INCH } \\
\hline Total & & & 950 & 163 & $* *$ & 29 \\
\hline Ryegrass & & & 595 & $4=125$ & $: *$ & 29 \\
\hline White clover & & .... & 346 & स* 29 & & nil \\
\hline Dead ryegrass leaf & and sheath & .... & 9 & & & nil \\
\hline Dead ryegrass flou & ver stem & $\ldots$ & nil & nil & & nil \\
\hline Dead clover & $\ldots \ldots=\ldots$ & $\ldots$ & nil & nil & & nil \\
\hline Pasture height (in & (............ & & $5-6$ & $2-3$ & & $1-2$ \\
\hline \multicolumn{7}{|l|}{ Below ONe InCH } \\
\hline Total & .......... & & 730 & $* 1,105$ & $(\div)$ & 874 \\
\hline Ryegrass & m.............. & & 202 & $* * 326$ & (N.S.) & ) 278 \\
\hline White clover & ……....... & $\ldots \ldots$ & 173 & $* 250$ & (N.S.) & 134 \\
\hline Dead ryegrass leaf & and sheath & $\ldots$ & 230 & * 413 & (N.S. & .) 365 \\
\hline Dead ryegrass flow & ver stem & & 86 & (N.S.)63 & (N.S.) & 48 \\
\hline Dead clover & $\ldots \ldots . . . . . .$. & $\ldots$ & 29 & (N.S.) 38( & (N.S.) & 38 \\
\hline Other species &..... & $\ldots$ & 10 & (N.S.) 15 & (N.S.) & 11 \\
\hline
\end{tabular}

(*) $P<0.1 \quad * P<0.05 \quad * * P<0.01$

The main features are the large reduction in yield above 1 in. as the pasture was grazed down, and the occurrence of nearly all the dead material in the bottom 1 in. of the sward. The increased yields in the bottom layer on the second day were probably the result of animal grazing and treading. Table 5 shows the spore counts on the individual herbage components for the three days of the experiment. 
TABLE 5: MEAN SPORE NUMBERS PER GRAM DRY WEIGHT $X 10^{3}$ ON THE INDIVIDUAL HERBAGE COMPONENTS

\begin{tabular}{|c|c|c|}
\hline Component & Spore & Numbers \\
\hline $\begin{array}{l}\text { Live ryegrass leaf } \\
\text { Live ryegrass stem } \\
\text { Live white clover } \\
\text { Live white clover stolon } \\
\text { Dead ryegrass leaf and sheath } \\
\text { Dead ryegrass flower stem }\end{array}$ & $\begin{array}{l}- \\
\cdot \\
\cdot \\
\cdot \\
-\end{array}$ & $\begin{array}{l}5.9 \pm 4.7 \\
8.5 \pm 4.0 \\
2.3 \pm 0.6 \\
85.1 \pm 13.7 \\
2,411 \mathrm{t}-265 \\
245 \pm 22\end{array}$ \\
\hline
\end{tabular}

The main features are the large proportion $(88 \%)$ ) of spores on dead ryegrass leaf and sheath and the small numbers on living material.

Table 6 shows the spore counts in two levels of the sward.

TABLE 6: MEAN SPORE NUMBERS PER GRAM DRY WEIGHT $\mathrm{X} 10^{\prime}$ ABOVE AND BELOW 1 INCH

\begin{tabular}{|c|c|c|c|}
\hline & Apr. 4 & $\begin{array}{l}\text { Date, } 1964 \\
\text { Apr. } 6\end{array}$ & Apr. 7 \\
\hline $\begin{array}{l}\text { Above } 1 \text { in. } \\
\text { Below } 1 \text { in. }\end{array}$ & $\begin{array}{c}2 \pm 1 \\
248 \pm 42 \\
*\end{array}$ & $\begin{array}{c}18 \pm 9 \\
331 \pm 106\end{array}$ & $\begin{array}{c}9 \pm 2 \\
322 \underset{(*)}{ \pm} 147\end{array}$ \\
\hline
\end{tabular}

(*) $P \overline{0.1} \quad * P<0.05$

The main feature is that most of the spores were below 1 in.

Table 7 summarizes the intake data collected from the oesophageal fistulated sheep.

TABLE 7: SPORE NUMBERS PER GRAM DRY WEIGHT X $10^{3}$ TOTAL HERBAGE (GRAMS DRY WEIGHT) AND PERCENTAGE' OF MAIN HERBAGE COMPONENTS IN EACH DAILY COLLECTION FROM THE OESOPHAGEAL FISTULATED SHEEP

\begin{tabular}{|c|c|c|c|c|c|}
\hline & Apr. 4 & & $\begin{array}{c}\text { Date, } 196 \\
\text { Apr. } 6\end{array}$ & & Apr. 7 \\
\hline $\begin{array}{l}\text { Spore numbers/ } \\
\text { g dry wt. X } 10^{3}\end{array}$ & $7 \pm 1$ & $*$ & $101 \pm 25$ & $(*)$ & $49 \pm 9$ \\
\hline $\begin{array}{l}\text { Total herbage } \\
\text { (g dry wt.)... }\end{array}$ & $.137 \pm 16$ & * & $33 \pm 12 N$ & $S$. & $70 \pm 23$ \\
\hline $\begin{array}{l}\text { \% Live ryegrass } \\
\% \text { Live white } \\
\text { clover } \\
\% \text { Dead ryegrass } \\
\text { leaf and sheath } \\
\% \text { Dead ryegrass } \\
\text { flower stem. }\end{array}$ & $\begin{array}{c}71 \pm 5 \\
26 \pm 5 \\
1.0 \pm 0.4 \\
\text { nil }\end{array}$ & $\begin{array}{c}\text { N.S. } \\
*\end{array}$ & $\begin{array}{r}80 \pm 6 \\
4 \pm 2 \\
16 \pm 6 \\
\text { nil }\end{array}$ & $\begin{array}{l}\text { N.S. } \\
* \\
\text { N.S. }\end{array}$ & $\begin{array}{c}72 \pm 3 \\
12 \pm 2 \\
9 \pm 2 \\
4.6 \pm 1.5\end{array}$ \\
\hline
\end{tabular}
(*) $P<0.1$
$* P<005$ 
The main features are the increased intake of spores and dead ryegrass as the pasture was more closely grazed. The slight fall in spore intake/ gram dry weight on the third day may have been due to the sheep eating well-rotted dead material which is not such a suitable substrate for the fungus as fresh material (Brook, 1963).

The results show that lax grazing of pastures may reduce spore intake and that intake of dead plant material may be an important factor in the occurrence of facial eczema.

\section{Conclusions}

Clearly any grazing management system for controlling facial eczema can be finally evaluated only during a severe outbreak of the disease. Although these conditions have not occurred during the course of this work, it is considered that some useful suggestions can be made. The partial replacement of Ruanui ryegrass by Manawa ryegrass on many sheep farms would facilitate the development of strongly clover-dominant pastures in the summer and early autumn. Provided these pastures are not allowed to grow too long, when they will produce large quantities of dead material, and are laxly grazed in breaks by means of an electric fence, it should be possible to both flush the ewes and reduce the incidence of facial eczema. If the Manawa ryegrass has virtually disappeared from the sward, it can be easily renewed later in the season by well-established methods of oversowing.

\section{Acknowledgements}

The authors wish to thank $\operatorname{Dr}$ C. S. W. Reid and P. Vlieg who fistulated the sheep ; E. J. Whitehouse and Miss M. N. Young for invaluable assistance; A. C. Glenday for some of the statistical analyses; $\mathrm{Dr}$ G. C. M. Latch for advice on the spore counting techniques; and $\mathrm{Dr}$ R. W. Brougham and $\operatorname{Dr}$ A. T. Johns for useful discussions.

\section{REFERENCES}

Arnold, G. W.; McManus, W. R.; Bush, I. G.; Ball, 3 ., 1964: Aust. J. exper. Agric \& anim. Husb. 4: 71

Barclay, P. C.. 1963: Proc. 25th Conf. N.Z. Grassl.Ass.,p. 128.

Brook, P. J., 1963: N.Z. J. agric. Res., 6: 147.

Brook, P. J.; Mutch, G. V., 1964: N.Z. J. agric. Res., 7: 138.

Brougham. R. W.. 1958: N.Z. J. agric. Res., 1: 707. 1960 : N.Z. J.agric. Res., $3: 125$.

Corkill, L., 1963: Proc. 25th Conf. N.Z. Grasst. Ass., p. 154. 
Filmer, J. F., 1960: N.Z. J. Agric, 101: 624.

Gilruth, J. Ä., 1897: Ann. Rep. N'Z. Dep. Agric., p. 58.

Johns, A. T.; Filmer, J. F., 1960: Proc. 8th Internut. Grassl. Congr., p. 661.

McMeekan, C. P., 1956: Sheepfmg. Annu. 1956, p. 21.

Nottingham, P. M.; Urselmann, A. J., 1961: N.Z. J. ugric. Res., 4: 449.

Sears, P. D., 1961: Proc. 23rd Conf. N.Z. Grassl. Ass., p. 39.

Sinclair, D. P., 1961: N.Z. J. agric. Res., 4: 492.

Sinclair, D. P.; Simpson, J. E. V., 1954: Proc. 16th Conf. N.Z. G rassl. Ass., p. 101.

Smith, J. D., 1964: N.Z. J. Agric., 108: 2.

Smith, J. D.; Crawley, W. E., 1964: N.Z. f. agric. Res., 7: 281. $5: 22$.

Smith, J. D. ; Lees, F. T.; Crawley, W. E., 1963: N.Z. J. agric. Res., $6: 518$.

Soper, K., '1958 : N.Z. J. agric. Res., 1: 329.

Synge, R. L. M.; White, E. P., 1959: Chem. \& Ind. (Rev.), p. 1546.

Thornton, R. H.; Percival., J. C., 1959: Nature [Lond.], 183: 63.

Torcll, D. T., 1954: J. antm. Sci., $13: 878$.

\section{DISCUSSION}

Has the speaker any idea of what can be done to avoid facial eczema in very dry years when there is little growth?

MR LANCASHIRE: In such conditions shutting up and feeding on hay would appear to be the only safe method available at present.

D. P. SINCLAIR: The results presented by Mr Lancashire agree with observations made at Manutuke over the years. 